\title{
Influence of Formononetin and $\mathrm{NaCl}$ on Mycorrhizal Colonization and Fusarium Crown and Root Rot of Asparagus
}

\author{
Wade H. Elmer, The Connecticut Agricultural Experiment Station, New Haven 06504
}

\begin{abstract}
Elmer, W. H. 2002. Influence of formononetin and $\mathrm{NaCl}$ on mycorrhizal colonization and Fusarium crown and root rot of asparagus. Plant Dis. 86:1318-1324.

Replanted asparagus fields commonly fail to produce a profitable stand due to alleopathic residues left behind from the previous asparagus crop, elevated densities of pathogenic Fusarium spp., and low densities of vesicular arbuscular mycorrhizae (VAM). Formononetin, a plant isoflavone that stimulates VAM spores to germinate, and sodium chloride $(\mathrm{NaCl})$, a diseasesuppressing amendment, were evaluated alone and in combination for their effect on reestablishing asparagus at two locations in abandoned asparagus fields. Greenhouse studies also were conducted with naturally and artificially infested soils. Formononetin was applied as a crown soak or soil drench, and $\mathrm{NaCl}$ was applied as a granular treatment. Feeder roots from soil cores sampled from field plots and from greenhouse transplants were assayed for colonization by VAM and for lesions caused by Fusarium oxysporum and F. proliferatum. Formononetin increased the number of VAM vesicles in roots from the field and greenhouse studies and reduced the percent root lesions caused by Fusarium spp. when compared with the nontreated controls. $\mathrm{NaCl}$ was more effective than formononetin in reducing the percentage of root lesions in both field and greenhouse experiment when compared with untreated plants but had no effect on VAM colonization. However, there was evidence that $\mathrm{NaCl}$ negated the effect of formononentin on VAM colonization. The $\mathrm{NaCl}$ treatment increased the May 2001 spear number by $15 \%$ and marketable spear weight by $23 \%$. At one site, treatment with formononetin increased mean number of stalks per plant by $29 \%$ in 2000 and $14 \%$ in 2001. Both formononetin and $\mathrm{NaCl}$ improve growth and reduce disease of asparagus in replanted asparagus and may be useful in reestablishing asparagus in abandoned asparagus field.
\end{abstract}

Additional keywords: Asparagus officinalis L., disease management, Fusarium oxysporum, F. proliferatum

Asparagus (Asparagus officinalis L.) is a popular vegetable grown in the United States. In New England, fresh asparagus production for roadside markets and pickyour-own operations have increased slowly over the past 10 years. These asparagus plantings remain profitable for 10 to 15 years when adequately managed. Over time, marketable yield declines as crowns die or crowns yield smaller and fewer spears. This condition is known as "asparagus decline" $(12,15)$. When old asparagus fields are replanted with asparagus, plants become stunted and chlorotic and usually do not reach a profitable state. This condition has been termed "replant problem" (15) or "early decline" (5).

Failure of asparagus to establish in abandoned asparagus fields is attributed to

Corresponding author: Wade H. Elmer
E-mail: wade.elmer@po.state.ct.us

This study was funded, in part, by VAMTech, Inc., Lansing, MI.

Accepted for publication 12 July 2002.

Publication no. D-2002-1003-01R

(C) 2002 The American Phytopathological Society alleopathy, Fusarium crown and root rot, and poor mycorrhizal root colonization. Direct inhibition of the asparagus plant can result from alleochemicals that are produced from old, decaying asparagus residues $(4,37)$. These toxins include ferulic acid, caffeic acid, cinnamic acid, and saponins $(16,19,44,45)$. Between 12 to 34 tons of asparagus residue/ha have been estimated to remain in the soil following crop removal (36). Roughly $10 \%$ of the residue was still detectable after 10 years (4), and one report found the effect persisted for up to 25 years after crop removal (34). Schofield et al. (36) reported the majority of the phytotoxins are released in the first few years, but the slow release of toxins from the decaying residue would probably last indefinitely. The removal of this plant material remains impracticable.

Another problem that contributes to the replant problem is elevated soil densities of Fusarium oxysporum (Schlechtend.) emend. W. C. Snyder \& H. N. Hans, and $F$. proliferatum (T. Matsushima) Nirenberg (Synanamorph $=$ F. moniliforme J. Sheld . emend. W. C. Snyder \& H. N. Hans). These species are causal to Fusarium crown and root rot disease $(7,21)$. Both species are commonly found in asparagus plantings (18), and are very damaging to young plants when present in high densities (14). A third factor that contributes to reestablishing asparagus is the effect of the toxins from root residues on soil microbes that may indirectly affect disease development. There are conflicting data as to whether these toxins directly enhance soil densities of Fusarium spp. or disease severity $(6,17,32)$, but all studies agree that Fusarium spp. are not affected by the toxins. These toxins, however, inhibit other fungi. Blok and Bollen (6) screened 112 fungal isolates, and found 31 isolates in seven fungal genera, including beneficial fungi such as Trichoderma spp. and Gliocladium spp., that were sensitive to the toxins. Other beneficial microbes, such as vesicular arbuscular mycorrhizae (VAM), also are affected by these toxins $(31,41)$. In vitro studies found that ferulic acid, a major alleochemical from asparagus, inhibited the hyphal elongation of Glomus fasciculatum (Thaxt. sensu Gerd.) Gerd. \& Trappe; (31). Pedersen et al. (41) reported that cinnamic acid derivatives decreased root colonization of asparagus feeder roots by VAM and that soil extracts from asparagus soils inhibited VAM colonization of asparagus roots. Early colonization of asparagus roots by VAM fungi can suppress infection by Fusarium spp. (2,27,42); therefore, rapid colonization of young roots by VAM may help to alleviate the damage caused to asparagus in replant situations.

One method to stimulate VAM colonization of roots is to apply formononetin, an isoflavone compound extracted from clover (28). Water-soluble K-salt formulations of formononetin are commercially available. Methods to reduce damage from Fusarium infection with fungicides have been ineffective or prohibitively expensive $(25,26)$. However, in declining fields, annual applications of sodium chloride $(\mathrm{NaCl})$ suppressed Fusarium crown and root rot and increased yields $(10,35)$. These applications do not benefit healthy plantings and may not have use as a preventative treatment (35; unpublished data). Additionally, there is concern over the use of $\mathrm{NaCl}$ in replant situations because salinity can adversely affect VAM infection $(1,22)$. The objectives of this study were to determine how applications of formononetin and $\mathrm{NaCl}$ treatments, alone and in combination, would affect VAM colonization, root disease, growth, and yield of asparagus grown in old asparagus fields. 


\section{MATERIALS AND METHODS}

Greenhouse experiments. The first greenhouse study examined formononetin, $\mathrm{NaCl}$, and VAM inoculant treatments in soil from an asparagus field that was artificially infested with Fusarium spp. The second greenhouse study was similar except the VAM inoculant was not added, and the soil was not artificially infested with Fusarium spp.

Seeds of 'Mary Washington' were agitated for $1 \mathrm{~h}$ in $20 \%$ household bleach $\left(0.105 \% \quad \mathrm{NaHClO}_{2}\right)$, rinsed three times with distilled $\mathrm{H}_{2} \mathrm{O}$, and soaked in distilled water at $30^{\circ} \mathrm{C}$ for $72 \mathrm{~h}$. Seeds were germinated in trays with 36 cells filled with potting mix (ProMix BX; Premier Brand Inc., New Rochelle, NY) and held for 10 weeks in the greenhouse. Seedlings received Hoagland's solution at $50 \mathrm{ml} /$ cell (20) after 4 weeks and were irrigated as needed with deionized $\mathrm{H}_{2} \mathrm{O}$. Seedlings were removed and the soil was washed from the roots. Seedlings with no root lesions that weighed between 5 and $7 \mathrm{~g}$ were selected for the experiments.

Potting mix was mixed at the rate of 2:1 (vol/vol) with natural soil that came from a field that had been cropped to asparagus for 9 years before being plowed under in June 1998 (greenhouse study 1). Soil was passed through a 5-mm sieve, mixed in a cement mixer, and stored in plastic-lined buckets in the greenhouse (11\% moisture). The soil mixture was infested with $F$. oxysporum (isolate FOA50) and F. proliferatum (95WT) by incorporating equal amounts of each isolate (millet inoculum at $0.5 \mathrm{~g} /$ liter of potting mix). Inoculum was prepared by placing $50 \mathrm{~g}$ of millet seed and $100 \mathrm{ml}$ of $\mathrm{H}_{2} \mathrm{O}$ into flasks and autoclaving for $1 \mathrm{~h}$ on two consecutive days. Flasks were seeded with three potato-dextroseagar plugs (4 $\mathrm{mm}$ in diameter) removed from the outer margins of an actively growing colony of either isolate. Cultures were incubated at room temperature and hand shaken for $15 \mathrm{~s}$ daily for 14 days. The colonized seed was air dried in autoclaved paper bags for 7 to 10 days. The dried, colonized seed was ground in a Wiley mill, passed through a 40-mesh sieve, and stored in glass jars at $4^{\circ} \mathrm{C}$. Millet inoculum was added to the potting mix by rotating the mixture it in a cement mixer for $20 \mathrm{~min}$.

At planting, the roots of 48 transplants were dusted with $2 \mathrm{~g}$ of Endomycorrhizal Inoculant (BEI Bio/Organics, La Pine, OR) which contained spores of $G$. brasilianun Spain \& De Miranda, G. clarum Nicolson \& Schenck, G. deserticola, Trappe, Bloss \& Menge, $G$. intraradices Schenck \& Smith, G. monosporum Gerdemann \& Trappe , G. mosseae (Nicolson \& Gerdemann) Gerdemann \& Trappe, and $\mathrm{Gi}^{-}$ gaspora margarita Becker \& Hall. An equal number of plants were not treated. Plants were put into 1.0-liter plastic pots filled with the soil mix (one plant/pot). One week after planting, pots receive 100 $\mathrm{ml}$ of one of four treatments: formononetin, $\mathrm{NaCl}$, both formononetin and $\mathrm{NaCl}$, or distilled $\mathrm{H}_{2} \mathrm{O}$. Formononetin was applied as a K-salt formulation (Myconate; VamTech Inc., Lansing, MI) using Myconate at $20 \mathrm{mg} / \mathrm{liter}$ of $\mathrm{H}_{2} \mathrm{O}$ and $\mathrm{NaCl}$ was applied at $10 \mathrm{~g} /$ liter of $\mathrm{H}_{2} \mathrm{O}$. Therefore, the eight combinations (four treatments $\times$ two VAM) were arranged as a randomized block design with 12 replicate pots/ treatment (four replicates/block). Plants were grown at temperatures of 15 to $20^{\circ} \mathrm{C}$ (night) and 20 to $25^{\circ} \mathrm{C}$ (day) under sodium vapor lamps set for 12-h-day, 12-h-night photoperiods. Plants were irrigated with deionized water as needed and fertilized twice a month with $100 \mathrm{ml}$ of Hoagland's solution/pot.

After 12 weeks, plants were removed from the pots, roots were washed with tap water to remove soil, and the fresh weights of the ferns and roots plus crown were recorded. Fern tissue was dried and reweighed. Root systems were divided in half. One half was assayed for disease as described below, and the other half was placed in formalin-acetic acid-alcohol (FAA) (33) until they could be assayed for VAM colonization. Feeder roots (1 to $2 \mathrm{~cm}$ long) were stained using the procedures of Phillips and Haymans (33), but modified to replace lactophenol with lactoglycerol (1.0 liter of lactic acid, $72 \mathrm{ml}$ of glycerol, and $72 \mathrm{ml}$ of $\mathrm{H}_{2} \mathrm{O}$ ). Colonization of feeder roots by VAM was determined by counting vesicles of VAM using the procedures of Kormanik and McGraw (24). Between 150 and 200 intersects were counted from each root system. Colonization by VAM was expressed as a percentage of the total intersects.

Disease severity and colonization by Fusarium spp. was determined by surface disinfesting roots for $4 \mathrm{~min}$ in $4 \%$ household bleach $\left(0.21 \% \mathrm{NaHClO}_{2}\right)$, rinsing in deionized water, and blotting the roots dry on paper towels. Feeder roots (1 to $4 \mathrm{~cm}$ long) were placed on Komada's Selective medium (23). The petri dish was placed over a $1-\mathrm{cm}$ grid and the total root length was estimated using the line-intersect method (39). The fraction of intersects with reddish lesions on the roots also was

Table 1. Analysis of variance for data on the effects of vesicular arbuscular mycorrhizae (VAM), formononetin, and NaCl on plant growth, VAM colonization, and Fusarium crown rot disease of asparagus grown in field soil in the greenhouse (greenhouse study 1$)^{t}$

\begin{tabular}{|c|c|c|c|c|c|c|c|}
\hline Source & df & $\begin{array}{c}\text { Plant fresh } \\
\text { weight }\end{array}$ & $\begin{array}{c}\text { Root fresh } \\
\text { weight }\end{array}$ & $\begin{array}{c}\text { Fern fresh } \\
\text { weight }\end{array}$ & $\begin{array}{l}\text { Fern dry } \\
\text { weight }\end{array}$ & $\begin{array}{l}\% \text { Root } \\
\text { lesions }^{u}\end{array}$ & $\% \mathbf{V A M}^{\mathbf{v}}$ \\
\hline Replicates & 11 & NS & NS & NS & NS & NS & NS \\
\hline VAM $^{\mathrm{w}}$ & 1 & NS & NS & NS & 0.014 & NS & $<0.001$ \\
\hline Form $^{\mathrm{x}}$ & 1 & NS & NS & 0.012 & NS & NS & NS \\
\hline $\mathrm{NaCl}^{\mathrm{y}}$ & 1 & $<0.001$ & $<0.001$ & 0.035 & NS & $<0.001$ & NS \\
\hline VAM $\times$ Form & 1 & 0.022 & NS & 0.046 & NS & NS & NS \\
\hline $\mathrm{VAM} \times \mathrm{NaCl}$ & 1 & NS & NS & NS & NS & NS & 0.041 \\
\hline $\mathrm{NaCl} \times$ Form & 1 & NS & NS & NS & NS & NS & NS \\
\hline $\mathrm{VAM} \times$ Form $\times \mathrm{NaCl}$ & 1 & NS & NS & NS & NS & NS & NS \\
\hline $\mathrm{Expt}^{\mathrm{Z}}$ & 1 & 0.031 & 0.042 & NS & NS & NS & NS \\
\hline Expt $\times$ VAM & 1 & NS & NS & NS & NS & NS & NS \\
\hline Expt $\times$ Form & 1 & NS & NS & NS & NS & NS & NS \\
\hline Expt $\times \mathrm{NaCl}$ & 1 & NS & NS & NS & NS & NS & NS \\
\hline Expt $\times$ VAM $\times$ Form & 1 & NS & NS & NS & NS & NS & NS \\
\hline Expt $\times \mathrm{VAM} \times \mathrm{NaCl}$ & 1 & NS & NS & NS & NS & NS & NS \\
\hline Expt $\times$ Form $\times \mathrm{NaCl}$ & 1 & NS & NS & NS & NS & NS & NS \\
\hline Expt $\times$ VAM $\times$ Form $\times \mathrm{NaCl}$ & 1 & NS & NS & NS & NS & NS & NS \\
\hline
\end{tabular}

${ }^{\mathrm{t}}$ Fresh and dry weight in grams; NS = not significant at $P=0.05$.

${ }^{u}$ Percent root lesions $=[$ (Number of intersects with root lesions/total intersects $\left.) \times 100\right]$.

${ }^{v}$ Percent colonization of feeder roots by VAM was determined by counting stained vesicles of VAM using the procedures of Kormanik and McGraw (24).

w VAM inoculant applied as endomycorrhizal inoculant, which contained spores of Glomus brasilianun Spain and De Miranda, G. clarum Nicolson and Schenck, G. deserticola, Trappe, Bloss and Menge, G. intraradices Schenck and Smith, G. monosporum Gerdemann and Trappe, G. mosseae (Nicolson and Gerdemann) Gerdemann and Trappe, and Gigaspora margarita Becker and Hall, at 2 g per root system.

${ }^{x}$ Formononetin applied in $100 \mathrm{ml}$ of $\mathrm{H}_{2} \mathrm{O}$ as a soil drench $(20 \mu \mathrm{g} / \mathrm{ml})$.

y $\mathrm{NaCl}$ applied in $100 \mathrm{ml}$ of $\mathrm{H}_{2} \mathrm{O}$ as $1 \% \mathrm{wt} / \mathrm{vol}$ solution.

${ }^{\mathrm{z}}$ Greenhouse study was repeated once approximately 1 year later. 
counted and used to estimate disease severity $(\%$ root lesions $=$ [number of intersects with root lesions/total intersects] $\times 100$ ). Root colonization by Fusarium spp. also was measured as another estimate of disease. Plates were incubated at room temperature for 5 days, and the number of Fusarium colonies that grew from the roots was counted and used to estimate root infection (Fusarium colonies/cm of feeder root). Between 1.5 and $2.0 \mathrm{~m}$ of feeder roots were sampled per plant. The experiment was repeated the following year.

Experiments using asparagus field soil that was naturally infested with Fusarium pathogens, asparagus residues, and VAM fungi were conducted as above with the following changes (greenhouse study 2). Soil (11\% moisture) was mixed with potting mix in a cement mixer at the rate of $1: 3$ ( $\mathrm{vol} / \mathrm{vol})$ soil:potting mix. Seedlings were grown as before and transplanted into 1.0-liter plastic pots filled with the soil medium. No artificial VAM inoculum was used and no artificial Fusarium inoculum was applied. One week later, pots received $100 \mathrm{ml}$ of one of four treatments: formononetin, $\mathrm{NaCl}$, both formononetin and $\mathrm{NaCl}$, or no treatment. Rates were as described above. The four treatments were arranged as a randomized block design with 12 replicate pots/treatment (4 replicates/block). Plants were grown and treated as described above. After 14 weeks, the study was terminated. Plant growth, disease severity, and VAM estimates were determined as described above. The experiment was repeated the next year.

Field studies. Field plots were established at two sites. Site 1 was planted 20 May 1999 in Windsor, CT on a fine loamy sand soil. The field had been in asparagus from 1983 to 1990 and from 1991 to 1996. Site 2 was planted on 18 May 1999 in Hamden, CT, on a sandy loam soil. The field had been cropped to asparagus from 1990 to 1998 . The plantings at both sites had declined due to Fusarium crown and root rot.

Fields were plowed in early May 1998, and trenches $30 \mathrm{~cm}$ deep were dug in rows $4.5 \mathrm{~m}$ long and $1.5 \mathrm{~m}$ apart. One-year-old crowns of 'Mary Washington' were purchased from nurseries and sorted into small, medium, and large crowns. At each site, 75 medium crowns were submerged for $20 \mathrm{~min}$ in 10 liters of a solution of formononetin ( $20 \mathrm{mg} / \mathrm{liter})$. Crowns were then planted $30 \mathrm{~cm}$ apart in 10 trenched rows (15 crowns/row). An equal number of crowns were similarly treated with tap water and planted in 10 trenched rows. Crowns were partially covered and then slowly filled in during the summer of 1999 as conventional for New England asparagus culture. On 22 to 24 June 1999, the $\mathrm{NaCl}$ treatment was applied at $280 \mathrm{~kg} / \mathrm{ha}$ to half of the formononetin-treated plots and half of the untreated plots. The formononetin treatment was applied again in 6 liters of water $(20 \mathrm{mg} / \mathrm{liter})$ using a watering can. The four treatments were applied to 20 rows at each site (5 replicate rows/treatment). Plots were arranged as a randomized block design (one plot/block). In June 2000, the four treatments were applied again. Formononetin was applied in 6.0 liters as described above, but $\mathrm{NaCl}$ was broadcast at the rate of $560 \mathrm{~kg} / \mathrm{ha}$ on the rows. All plots were treated with $\mathrm{N}$ (as $\mathrm{NH}_{4} \mathrm{NO}_{3}$ ) at $56 \mathrm{~kg} / \mathrm{ha}$ and $\mathrm{K}\left(\right.$ as $\left.\mathrm{K}_{2} \mathrm{SO}_{4}\right)$ at $50 \mathrm{~kg} / \mathrm{ha}$ at planting and in spring of 2000 and 2001. Phosphorus was not applied because soil tests revealed sufficient $\mathrm{P}$ and because high $\mathrm{P}$ conditions inhibit VAM colonization (30). Weeds were removed by hand in 1999. In 2000 and 2001, glyphosate was applied before the spears emerged in the spring, and applications of metribuzin and napropamide were applied at labeled rates in June.

Roots were sampled from field plots in July 1999 and July 2000 by removing soil cores ( 22.5 by $3 \mathrm{~cm}$ in diameter) with a soil auger. Fifteen soil cores were removed from each row (one core/plant) approximately 12 to $15 \mathrm{~cm}$ from the crown and bulked. Roots were extracted from the soil cores by passing the soil through a $2.8-\mathrm{mm}$ sieve with a low stream of water and collecting roots with forceps. Roots were washed in tap water. One half of the roots were placed in FAA and later stained for VAM as described above. The remaining roots were surface disinfested and assayed for lesions and infection by Fusarium spp as described above.

In June 1999, May 2000, and July 2001, the number of stalks per crown was recorded and expressed as stand counts. Asparagus typically is not harvested until the second year after planting crowns. Spears were cut three times a week beginning 25 April 2001 and lasting until 18 May for a total of 10 harvests. Spears $22 \mathrm{~cm}$ or longer in each plot were cut, counted, and weighed and then trimmed to $22 \mathrm{~cm}$ and reweighed.

Statistical procedures. Data based on percentages were transformed to the arcsine of the square root before analysis. All data were analyzed as factorials experiments using analysis of variance. Both greenhouse studies were repeated and included in all analyses. Means were separated using Bonferroni's Test at $P=0.05$.

Table 2. Effect of vesicular arbuscular mycorrhizae (VAM), formononetin, and $\mathrm{NaCl}$ on plant growth, VAM colonization, and Fusarium crown rot disease of asparagus grown in field soil in the greenhouse (greenhouse study 1$)^{\mathrm{u}}$

\begin{tabular}{|c|c|c|c|c|c|c|c|c|}
\hline $\mathbf{V A M}^{\mathbf{v}}$ & Form $^{w}$ & $\mathrm{NaCl}^{\mathrm{x}}$ & $\begin{array}{c}\text { Plant fresh } \\
\text { weight }\end{array}$ & $\begin{array}{c}\text { Root fresh } \\
\text { weight }\end{array}$ & $\begin{array}{c}\text { Fern fresh } \\
\text { weight }\end{array}$ & $\begin{array}{c}\text { Fern dry } \\
\text { weight }\end{array}$ & $\begin{array}{l}\text { \% Root } \\
\text { lesions }^{\mathrm{y}}\end{array}$ & $\% \mathbf{V A M}^{\mathrm{z}}$ \\
\hline \multicolumn{9}{|c|}{ VAM $\times$ Form } \\
\hline- & + & \pm & $36.3 \mathrm{~b}$ & NS & $6.9 \mathrm{ab}$ & NS & NS & NS \\
\hline - & - & \pm & $31.0 \mathrm{a}$ & NS & $6.1 \mathrm{a}$ & NS & NS & NS \\
\hline+ & + & \pm & $34.8 \mathrm{ab}$ & NS & $7.2 \mathrm{ab}$ & NS & NS & NS \\
\hline+ & - & \pm & $33.0 \mathrm{ab}$ & NS & $8.2 \mathrm{~b}$ & NS & NS & NS \\
\hline \multicolumn{9}{|c|}{$\mathrm{VAM} \times \mathrm{NaCl}$} \\
\hline- & \pm & + & NS & NS & NS & NS & NS & $15.0 \mathrm{ab}$ \\
\hline - & \pm & - & NS & NS & NS & NS & NS & $8.3 \mathrm{a}$ \\
\hline+ & \pm & + & NS & NS & NS & NS & NS & $30.6 b c$ \\
\hline+ & \pm & - & NS & NS & NS & NS & NS & $38.1 \mathrm{c}$ \\
\hline \multicolumn{9}{|l|}{ VAM } \\
\hline+ & \pm & \pm & NS & NS & NS & 2.0 & NS & NS \\
\hline- & \pm & \pm & NS & NS & NS & 1.8 & NS & NS \\
\hline \multicolumn{9}{|l|}{ NACL } \\
\hline \pm & \pm & + & 38.6 & 31.1 & 7.6 & NS & 24.0 & NS \\
\hline \pm & \pm & - & 28.9 & 22.4 & 6.6 & NS & 38.9 & NS \\
\hline
\end{tabular}

" Values represent the mean of 24 replicate plants; 12 replicates/experiment; fresh and dry weight in grams; NS $=$ not significant at $P=0.05$.

v VAM inoculant applied as $2 \mathrm{~g}$ of endomycorrhizal inoculant per root system which contained spores of Glomus brasilianun Spain and De Miranda, G.

clarum Nicolson and Schenck, G. deserticola, Trappe, Bloss and Menge, G. intraradices Schenck and Smith, G. monosporum Gerdemann and Trappe ,

G. mosseae (Nicolson and Gerdemann) Gerdemann and Trappe, and Gigaspora margarita Becker and Hall.

${ }^{\text {w }}$ Formononetin applied in $100 \mathrm{ml}$ of $\mathrm{H}_{2} \mathrm{O}$ as a soil drench $(20 \mu \mathrm{g} / \mathrm{ml})$.

${ }^{x} \mathrm{NaCl}$ applied in $100 \mathrm{ml}$ of $\mathrm{H}_{2} \mathrm{O}$ as $1 \% \mathrm{wt} / \mathrm{vol}$ solution.

y Percent root lesions $=[$ (Number of intersects with root lesions/total intersects $) \times 100]$.

${ }^{\mathrm{z}}$ Percent colonization of feeder roots by VAM was determined by counting stained vesicles of VAM using the procedures of Kormanik and McGraw (24). 
Analyses were conducted using Systat 10 (SPSS, Inc. Chicago, IL).

\section{RESULTS}

Greenhouse studies. In the first greenhouse study where VAM inoculant was used in the soil mixture, there was a VAMformononetin interaction for fresh plant weight $(P=0.022)$ and fresh fern weight $(P=0.046)$ data (Table 1). Plants grown without the VAM inoculants had $17 \%$ more plant fresh weight and $13 \%$ more fern fresh weight when treated with formononetin, whereas plants grown with VAM inoculant had only a $5 \%$ decrease in fresh plant weight and $13 \%$ reduction in fern fresh weight when compared with plants not treated with formononetin Table 2). Plants treated with $\mathrm{NaCl}$ had $34 \%$ more fresh weight $(P<0.001), 39 \%$ more root weight $(P<0.001)$, and $15 \%$ fern weight $(P=$ $0.035)$ than nontreated plants. In the absence of VAM, formononetin increased the fern fresh weight by $17 \%(P=0.046)$, but not when VAM was present. The VAM inoculant increased the fern dry weight by $11 \%(P=0.014)$ when compared with nontreated plants. Plants treated with $\mathrm{NaCl}$ had a $39 \%$ reduction in the percentage of roots with lesions $(P<0.001)$. An interac- tion between VAM inoculant and $\mathrm{NaCl}$ was detected on VAM colonization $(P=0.041)$. Plants grown without the VAM inoculant had $84 \%$ more VAM colonization when $\mathrm{NaCl}$ was applied, but $\mathrm{NaCl}$ caused a $20 \%$ reduction in colonization in the presence of VAM inoculant. The amount of root colonization by Fusarium spp. was not significantly affected by treatment and averaged 0.76 colonies of Fusarium spp. per centimeter of root. The repetition of the study was similar to the first trial, except plant fresh weight and root fresh weight was 21 and $25 \%$ greater in the second trial (data not shown).

In the second greenhouse study, there were no treatment interactions or treatment-experiment interactions on plant growth or disease estimates (Table 3). There was an interaction between formononetin and $\mathrm{NaCl}$ on VAM colonization $(P=0.028)$. Formononetin increased the colonization by VAM by almost threefold when $\mathrm{NaCl}$ was absent, but the effect was negated when $\mathrm{NaCl}$ was present (Table 4). Formononetin decreased root lesions by 18 $\%(P=0.037)$. Plants treated with $\mathrm{NaCl}$ had $14 \%$ more fresh weight $(P<0.001)$, $15 \%$ more root weight $(P<0.001), 7 \%$ more fern fresh weight $(P=0.05)$, and
$45 \%$ reduction in the percentage of root lesions $(P<0.001)$ than nontreated plants. The number of colonies of Fusarium spp. that grew from the roots was not affected by treatment and averaged 0.45 colonies of Fusarium spp. per centimeter of root.

Field studies. There were no interactions between site and treatments on the percentage of root lesions or percentage of VAM colonization (Table 5). The application of formononetin reduced the percentage of root lesions in 2000 by $25 \%$ ( $P=$ 0.035), but had no effect in 1999 (Table 6). The percentage of VAM colonization of the roots was increased in formononetintreated plants by $129 \%(P<0.001)$ in 1999 and by $48 \%(P=0.003)$ in 2000. Applying $\mathrm{NaCl}$ reduced the percentage of root lesions by $33 \%$ in $1999(P=0.042)$ and by $30 \%$ in $2000(P=0.007)$. There was no effect of $\mathrm{NaCl}$ on VAM colonization in the field. The percent of root lesions in 1999 $(P=0.035)$ and VAM colonization in 2000 $(P<0.001)$ were greater in Hamden than in Windsor, but VAM colonization in 1999 was greater in Windsor $(P=0.003)$. Root colonization by Fusarium spp. was not affected by treatment, and averaged 0.27 colonies of Fusarium spp. per centimeter of root.

Table 3. Analysis of variance of the data on the effects of formononetin and $\mathrm{NaCl}$ on asparagus growth and Fusarium crown and root rot when grown in asparagus field soil naturally infested with vesicular arbuscular mycorrhizae (VAM) and Fusarium oxysporum and F. proliferatum (greenhouse study 2) ${ }^{\mathrm{u}}$

\begin{tabular}{|c|c|c|c|c|c|c|c|}
\hline Source & df & $\begin{array}{c}\text { Plant fresh } \\
\text { weight }\end{array}$ & $\begin{array}{c}\text { Root fresh } \\
\text { weight }\end{array}$ & $\begin{array}{c}\text { Fern fresh } \\
\text { weight }\end{array}$ & $\begin{array}{c}\text { Fern dry } \\
\text { weight }\end{array}$ & $\begin{array}{l}\text { \% Root } \\
\text { lesions }^{v}\end{array}$ & $\%$ VAM $^{w}$ \\
\hline Replicates & 11 & NS & NS & NS & NS & NS & NS \\
\hline Form $^{x}$ & 1 & NS & NS & NS & NS & 0.037 & 0.042 \\
\hline $\mathrm{NaCl}^{\mathrm{y}}$ & 1 & $<0.001$ & $<0.001$ & 0.050 & NS & $<0.001$ & NS \\
\hline Form $\times \mathrm{NaCl}$ & 1 & NS & NS & NS & NS & NS & 0.028 \\
\hline $\operatorname{Expt}^{\mathrm{Z}}$ & 1 & $<0.001$ & $<0.001$ & $<0.001$ & NS & $<0.001$ & NS \\
\hline Expt $\times$ Form & 1 & NS & NS & NS & NS & NS & NS \\
\hline Expt $\times \mathrm{NaCl}$ & 1 & NS & NS & NS & NS & NS & NS \\
\hline Expt $\times$ Form $\times \mathrm{NaCl}$ & 1 & NS & NS & NS & NS & NS & NS \\
\hline
\end{tabular}

u Fresh and dry weight in grams; NS = not significant at $P=0.05$.

$\checkmark$ Percent root lesions $=[$ (Number of intersects with root lesions/total intersects $) \times 100]$.

${ }^{w}$ Percent colonization of feeder roots by VAM was determined by counting stained vesicles of VAM using the procedures of Kormanik and McGraw (24).

${ }^{\mathrm{x}}$ Formononetin applied in 100 of $\mathrm{ml} \mathrm{H}_{2} \mathrm{O}$ as a soil drench $(20 \mu \mathrm{g} / \mathrm{ml})$.

${ }^{y} \mathrm{NaCl}$ applied in $100 \mathrm{ml}$ of $\mathrm{H}_{2} \mathrm{O}$ as $1 \% \mathrm{wt} / \mathrm{vol}$ solution.

${ }^{\mathrm{z}}$ Greenhouse study was repeated once approximately 1 year later.

Table 4. Effect of formononetin and $\mathrm{NaCl}$ on asparagus growth and Fusarium crown and root rot when grown in asparagus field soil naturally infested with vesicular arbuscular mycorrhizae (VAM) and Fusarium oxysporum and F. proliferatum (greenhouse study 2$)^{\mathrm{v}}$

\begin{tabular}{|c|c|c|c|c|c|c|}
\hline Form $^{w}$ & $\mathrm{NaCl}^{\mathrm{x}}$ & Total fresh weight & Root fresh weight & Fern fresh weight & $\%$ Root lesions $^{y}$ & \% Colonization by VAM ${ }^{z}$ \\
\hline \multicolumn{7}{|c|}{ Form $\times \mathrm{NaCl}$} \\
\hline- & - & NS & NS & NS & NS & $8.2 \mathrm{a}$ \\
\hline- & + & NS & NS & NS & NS & $11.0 \mathrm{ab}$ \\
\hline+ & - & NS & NS & NS & NS & $23.4 \mathrm{~b}$ \\
\hline+ & + & NS & NS & NS & NS & $11.3 \mathrm{ab}$ \\
\hline \multicolumn{7}{|l|}{ Form } \\
\hline+ & \pm & NS & NS & NS & 20.7 & NS \\
\hline- & \pm & NS & NS & NS & 25.3 & NS \\
\hline \multicolumn{7}{|l|}{$\mathrm{NaCl}$} \\
\hline \pm & + & 31.2 & 24.4 & 6.8 & 16.2 & NS \\
\hline \pm & - & 27.3 & 21.0 & 6.3 & 29.8 & NS \\
\hline
\end{tabular}

${ }^{\mathrm{v}}$ Values represent the mean of 22 replicate plants; 12 replicates from the first experiment and 10 replicates from the repetition; fresh and dry weight in grams; NS = not significant at $P=0.05$; values followed by the same letters are not significantly different using Bonferonni's Test at $P \leq 0.05$.

${ }^{\text {w }}$ Formononetin applied in $100 \mathrm{ml}$ of $\mathrm{H}_{2} \mathrm{O}$ as a soil drench $(20 \mu \mathrm{g} / \mathrm{ml})$.

${ }^{x} \mathrm{NaCl}$ applied in $100 \mathrm{ml}$ of $\mathrm{H}_{2} \mathrm{O}$ as $1 \% \mathrm{wt} / \mathrm{vol}$ solution.

y Percent root lesions $=[$ (No. intersects with root lesions/total intersects $) \times 100]$.

${ }^{\mathrm{z}}$ Percent colonization of feeder roots by VAM was determined by counting stained vesicles of VAM using the procedures of Kormanik and McGraw (24). 
Growth variables were affected by treatment and site in the field plots (Table 7). An interaction between the site and formononetin treatment occurred on mean stalk per plant measured in May $2000(P=0.025)$ and July $2001(P=$ 0.041). In Hamden, formononetin promoted stalk growth by $29 \%$ in 2000 and $13 \%$ in 2001, but the response in Windsor was less than $1 \%$ (Table 8). Although it just missed significance $(P=$ 0.063), spear numbers in Hamden tended to be greater when treated with formononetin than those without formononetin (data not shown). Compared with untreated plots, the $\mathrm{NaCl}$ treatment increased spear number by $14 \%(P=$ $0.042)$, total spear weight by $23 \%(P=$ 0.002 ), and marketable spear weight by $23 \%(P=0.003)$. Although the number of spears did not differ between the sites, total and marketable yield were $18 \%$ greater in Hamden than Windsor.

\section{DISCUSSION}

There are multiple problems associated with replanting asparagus fields. These include alleopathy $(4,5,17,32,34,37,45)$, root infection by Fusarium spp. $(14,15)$, and poor mycorrhizal colonization $(31,41)$. These limitations have forced several growers to relocate to new areas or limit their production. The need for new asparagus land has been critical in Europe (4) and the United States for many years (15). The current study attempted to alleviate the damage in replanted fields by applying two treatments, formononetin to enhance VAM colonization and $\mathrm{NaCl}$ to suppress Fusarium infection, and to determine whether they interacted with each other. No statistical interactions occurred between these

Table 5. Analysis of variance for the data of the effects of formononetin and $\mathrm{NaCl}$ on incidence of asparagus root lesions caused by Fusarium oxysporum and F. proliferatum, and on the incidence of vesicular arbuscular mycorrhizal (VAM) colonization of asparagus grown in Hamden, CT and Windsor, CT on soils previously cropped to asparagus ${ }^{\mathrm{u}}$

\begin{tabular}{|c|c|c|c|c|c|}
\hline \multirow[b]{2}{*}{ Factors } & \multirow[b]{2}{*}{ df } & \multicolumn{2}{|c|}{$\%$ Root lesions $^{\mathrm{v}}$} & \multicolumn{2}{|c|}{$\%$ Colonization by VAM } \\
\hline & & 1999 & 2000 & 1999 & 2000 \\
\hline Replicates & 4 & NS & NS & NS & NS \\
\hline Form $^{\mathrm{x}}$ & 1 & NS & 0.035 & $<0.001$ & 0.003 \\
\hline $\mathrm{NaCl}^{\mathrm{y}}$ & 1 & 0.042 & 0.007 & NS & NS \\
\hline Site $^{z}$ & 1 & 0.035 & NS & 0.003 & $<0.001$ \\
\hline Site $\times$ Form & 1 & NS & NS & NS & NS \\
\hline Site $\times \mathrm{NaCl}$ & 1 & NS & NS & NS & NS \\
\hline Form $\times \mathrm{NaCl}$ & 1 & NS & NS & NS & NS \\
\hline Site $\times$ Form $\times \mathrm{NaCl}$ & 1 & NS & NS & NS & NS \\
\hline
\end{tabular}

u NS = not significant at $P=0.05$.

${ }^{v}$ Percent root lesions $=[($ Number of root intersects with root lesions/total intersects $) \times 100]$.

${ }^{\mathrm{w}}$ Percent colonization of feeder roots by VAM was determined by counting stained vesicles of VAM using the procedures of Kormanik and McGraw (24).

${ }^{\mathrm{x}}$ Formononetin $(20 \mu \mathrm{g} / \mathrm{ml})$ applied as a crown soak for $20 \mathrm{~min}$ at planting (May 1999) and as a crown drench (June 1999 and June 2000) at 6.0 liters/row $(20 \mu \mathrm{g} / \mathrm{ml})$.

y $\mathrm{NaCl}$ applied in June 1999 at $280 \mathrm{~kg} / \mathrm{ha}$ and June 200 at $560 \mathrm{~kg} / \mathrm{ha}$.

${ }^{z}$ Two sites: Hamden, CT (sandy loam soil) and Windsor, CT (fine loamy sand soil); five replicates/site.

Table 6. Effect of formononetin and $\mathrm{NaCl}$ on incidence of asparagus root lesions caused by Fusarium oxysporum and $F$. proliferatum, and on the incidence of vesicular arbuscular mycorrhizal (VAM) colonization of asparagus grown in Hamden, CT and Windsor, CT on soils previously cropped to asparagus ${ }^{\mathrm{u}}$

\begin{tabular}{|c|c|c|c|c|c|c|}
\hline \multirow[b]{2}{*}{ Formononetin } & \multirow[b]{2}{*}{$\mathrm{NaCl}$} & \multirow[b]{2}{*}{ Site } & \multicolumn{2}{|c|}{ Root lesions $^{v}$} & \multicolumn{2}{|c|}{$\%$ Colonization by VAM } \\
\hline & & & 1999 & 2000 & 1999 & 2000 \\
\hline \multicolumn{7}{|l|}{ Form $^{\mathrm{x}}$} \\
\hline+ & \pm & \pm & NS & 16.2 & 33.4 & 35.9 \\
\hline- & \pm & \pm & NS & 21.7 & 14.6 & 24.2 \\
\hline \multicolumn{7}{|l|}{$\mathrm{NaCl}^{\mathrm{y}}$} \\
\hline \pm & + & \pm & 12.7 & 15.5 & NS & NS \\
\hline \pm & - & \pm & 19.0 & 22.0 & NS & NS \\
\hline \multicolumn{7}{|l|}{ Site $^{z}$} \\
\hline \pm & \pm & Hamden & 19.2 & NS & 17.5 & 36.9 \\
\hline \pm & \pm & Windsor & 12.5 & NS & 30.5 & 23.2 \\
\hline
\end{tabular}

u NS = not significant at $P=0.05$.

${ }^{\mathrm{v}}$ Percent root lesions $=[($ Number of root intersects with root lesions/total intersects $) \times 100]$.

w Percent colonization of feeder roots by VAM was determined by counting stained vesicles of VAM using the procedures of Kormanik and McGraw (24).

${ }^{\mathrm{x}}$ Formononetin $(20 \mu \mathrm{g} / \mathrm{ml})$ applied as a crown soak for $20 \mathrm{~min}$ at planting (May 1999) and as a crown drench (June 1999 and June 2000) at 6.0 liters/row $(20 \mu \mathrm{g} / \mathrm{ml})$.

y $\mathrm{NaCl}$ applied in June 1999 at $280 \mathrm{~kg} / \mathrm{ha}$ and June 200 at $560 \mathrm{~kg} / \mathrm{ha}$.

${ }^{\text {z }}$ Hamden, CT (sandy loam soil) and Windsor, CT (fine loamy sand soil); five replicates/site. treatments in the field or the greenhouse except for one greenhouse study where applying $\mathrm{NaCl}$ negated the effects of formononetin on VAM colonization. In contrast, the effect on VAM was not observed in field tests. The $\mathrm{NaCl}$ and formononetin treatments both decreased the percentage of lesions observed on feeder roots and both treatments increased growth in Hamden, but only $\mathrm{NaCl}$ affected growth in Windsor. Although the disease-suppressing ability of formononetin did not result in increase yield in 2001, the effect may increase field longevity. Establishment of a vigorous, healthy stand is a major objective in replanting old asparagus fields The combination of these two products may be useful in reestablishing asparagus in old, abandoned asparagus fields.

The underlying mechanism of how formononetin stimulates VAM and affects Fusarium crown and root rot in asparagus was not addressed by this study. However, flavonoid compounds like formononetin are naturally produced by legumes, and are implicated in inducing Rhizobium nodulation along with increasing VAM colonization (38). Although symbiosis between nonlegume roots and VAM does not require flavonoids (3), these compounds can benefit nonlegume plants by enhancing VAM associations when VAM propagules are low (38). This may explain why, in the first greenhouse study, formononetin had no effect on plant weight when additional VAM inoculant was added, but increased growth when low resident soil levels were present. The sensitivity of the Fusarium pathogens to formononetin was not determined but, at the rates used in the current study, it is unlikely that microbes other than VAM were affected because formononetin is reported as being non toxic at these rates (9) and is quickly degraded by microbes (29). Formononetin's mode of action in suppressing Fusarium spp. may be an indirect effect by enhancing VAM colonization and boosting vigor because VAM does improved plant growth (42). On the other hand, formononetin is listed as a phytoalexin (40) and also may affect disease directly via defense pathways in the plant.

Similarly, the mechanism of how $\mathrm{NaCl}$ suppresses Fusarium crown and root rot has not been completely deciphered, but it is unlikely that $\mathrm{NaCl}$ affects the same processes activated by formononetin. At these rates, $\mathrm{NaCl}$ had no fungicidal activity (10). In fact, the current study found that $\mathrm{NaCl}$ did not alter the number of colonies that grew from the roots. However, the colonies were not all identified or tested for pathogenicity; therefore, it is not possible to determine whether that fraction of pathogenic Fusarium spp. in soil was altered by the treatments. $\mathrm{NaCl}$ applications may influence disease by its effect on lowering fern water potential, changing root composition, and altering microbial com- 
munities in the rhizosphere $(11,13)$. Split root studies indicated that some of the effect of $\mathrm{NaCl}$ is systemically translocated through the root system (unpublished data).

Another potential benefit of $\mathrm{NaCl}$ in replanted asparagus soil could be its effect on displacing toxic phenols from soil colloids. Dalton et al. (8) reported that $\mathrm{Na}-$ EDTA in water at neutral $\mathrm{pH}$ would remove more ferulic acid from soil than at lower $\mathrm{pH}$ or with other extractants. The effect of $\mathrm{NaCl}$ as an extractant of alleochemicals in neutral asparagus soils is not known. However, saline solutions commonly are used to elute many biologically active components from ion exchange columns. Further research might determine whether or not $\mathrm{NaCl}$ is effective in removing alleochemicals from soil. This may explain why alleopathy is not damaging to wild stands of asparagus that thrive in brackish habitats (43) or in production areas in Australia where saline levels rise and fall with the ground water (unpub- lished data), or why $\mathrm{NaCl}$ is ineffective in healthy plantings (35; unpublished data) where alleochemicals may not have accumulated to damaging levels.

In summary, the replant problems remain unresolved and will continue to make serious inroads into asparagus production because growers either must choose to relocate to new lands or suffer damage when they reestablish their crops. When circumstances force the later choice, the use of $\mathrm{NaCl}$ may provide immediate benefits in suppressing disease and increasing yields. Formononetin's ability to reduce disease and improve stand establishment was marginal, but it may possibly extend the life of the planting. The longterm value of these treatments on yield and field longevity in replanted fields has yet to be determined.

\section{ACKNOWLEDGMENTS}

I thank B. O'Dowd for technical and field assistance; S. Kluk, Y. Williams, E. Naughton, R. Horvath, R. Cecarelli, and R. Hannan for field assistance; Jack Kelly for samples of Myconate;
A. Rinehart for helpful advise on mycorrhizae staining; and C. Elmer, I. Elmer, and M. Elmer for assistance with harvesting.

\section{LITERATURE CITED}

1. Abbott, L. K., Juniper, S., and McMillen, B. G. 1998. Inhibition of hyphal growth of a vesicular-arbuscular mycorrhizal fungus in soil containing sodium chloride limits the spread of infection from spores. Soil Biol. Biochem. 30:1639-1646.

2. Arriola, L., Hausbeck, M. K., Rogers, J., and Safir, G. R. 2000. The effect of Trichodermaharzianum and arbuscular mycorrhizae on Fusarium root rot in asparagus. Horttechnology 10:141-144.

3. Becard, G., Taylor, L. P., Douds, D. D., Pfeffer, P. E., and Doner, L. W. 1995. Flavonoids are not necessary plant signal compounds in arbuscular mycorrhizal symbioses. Mol. PlantMicrobe Interact. 8:252-258.

4. Blok, W. J., and Bollen, G. J. 1993. The role of autotoxins from root residues from the previous crop in the replant disease of asparagus. Neth. J. Plant Pathol. 99 (Suppl. 3):29-40.

5. Blok, W. J., and Bollen, G. J. 1996. Etiology of asparagus replant bound early decline. Eur. J. Plant Pathol. 102:87-98.

6. Blok, W. J., and Bollen, G. J. 1996. Interactions of asparagus root tissue with soil microorgan-

Table 7. Analysis of variance for the data of the effects of formononetin and $\mathrm{NaCl}$ on the mean asparagus stalk per plant in 2000 and 2001 and on the 2001 spear yield of asparagus grown in Hamden, CT and Windsor, CT on soils previously cropped to asparagus ${ }^{u}$

\begin{tabular}{|c|c|c|c|c|c|c|}
\hline \multirow[b]{2}{*}{ Source } & \multirow[b]{2}{*}{ df } & \multicolumn{2}{|c|}{ No. stalks/plant } & \multicolumn{3}{|c|}{ Spring 2001} \\
\hline & & May 2000 & July 2001 & No. spears & Untrimmed spear weight & Marketable spear weight ${ }^{v}$ \\
\hline Replicates & 4 & NS & NS & NS & NS & NS \\
\hline Form $^{\mathrm{w}}$ & 1 & 0.033 & 0.036 & NS & NS & NS \\
\hline $\mathrm{NaCl}^{\mathrm{x}}$ & 1 & NS & NS & 0.042 & 0.002 & 0.003 \\
\hline Site $^{\mathrm{y}}$ & 1 & NS & NS & NS & 0.001 & 0.002 \\
\hline Site $\times$ Form & 1 & 0.025 & 0.041 & $\mathrm{NS}^{\mathrm{z}}$ & NS & NS \\
\hline Site $\times \mathrm{NaCl}$ & 1 & NS & NS & NS & NS & NS \\
\hline Form $\times \mathrm{NaCl}$ & 1 & NS & NS & NS & NS & NS \\
\hline Site $\times$ Form $\times \mathrm{NaCl}$ & 1 & NS & NS & NS & NS & NS \\
\hline
\end{tabular}

u NS = not significant at $P=0.05$.

${ }^{\mathrm{v}}$ Marketable yield/ha $=$ spear weight trimmed to $22.5 \mathrm{~cm}$.

${ }^{\mathrm{x}}$ Formononetin $(20 \mu \mathrm{g} / \mathrm{ml})$ applied as a crown soak for $20 \mathrm{~min}$ at planting (May 1999) and as a crown drench (June 1999 and June 2000$)$ at 6.0 liters/row $(20 \mu \mathrm{g} / \mathrm{ml})$.

${ }^{x} \mathrm{NaCl}$ applied in June 1999 at $280 \mathrm{~kg} / \mathrm{ha}$ and June 200 at $560 \mathrm{~kg} / \mathrm{ha}$.

y Hamden, CT (sandy loam soil) and Windsor, CT (fine loamy sand soil); five replicates/site.

z Term was significant at $P=0.063$.

Table 8. Effect of formononetin and $\mathrm{NaCl}$ on the mean asparagus stalk/plant in 2000 and 2001 and on the 2001 spear yield of asparagus grown in Hamden, CT and Windsor, CT on soils previously cropped to asparagus ${ }^{t}$

\begin{tabular}{|c|c|c|c|c|c|c|c|}
\hline \multirow[b]{2}{*}{ Sitew $^{w}$} & \multirow[b]{2}{*}{ Form $^{x}$} & \multirow[b]{2}{*}{$\mathrm{NaCl}^{\mathbf{y}}$} & \multicolumn{2}{|c|}{ No. stalks/plant ${ }^{u}$} & \multicolumn{3}{|c|}{ Spring $2001^{v}$} \\
\hline & & & May 2000 & July 2001 & No. of spears & Untrimmed spear weight & Marketable spear weight \\
\hline \multicolumn{8}{|c|}{ Site $\times$ Form } \\
\hline Hamden & + & \pm & $61.1 \mathrm{~b}$ & $81.0 \mathrm{a}$ & $\mathrm{NS}^{\mathrm{z}}$ & NS & NS \\
\hline Hamden & - & \pm & $47.5 \mathrm{a}$ & $71.4 \mathrm{~b}$ & NS & NS & NS \\
\hline Windsor & + & \pm & $55.4 \mathrm{ab}$ & $63.4 \mathrm{~b}$ & NS & NS & NS \\
\hline Windsor & - & \pm & $55.8 \mathrm{ab}$ & $61.9 \mathrm{~b}$ & NS & NS & NS \\
\hline \multicolumn{8}{|l|}{ Site } \\
\hline Hamden & \pm & \pm & NS & NS & NS & $2,223.6$ & $1,547.8$ \\
\hline Windsor & \pm & \pm & NS & NS & NS & $1,885.7$ & $1,312.6$ \\
\hline \multicolumn{8}{|l|}{$\mathrm{NaCl}$} \\
\hline \pm & \pm & + & NS & NS & 89.1 & $2,266.1$ & $1,577.4$ \\
\hline \pm & \pm & - & NS & NS & 78.2 & $1,843.2$ & $1,283.0$ \\
\hline
\end{tabular}

t NS $=$ not significant at $P=0.05$

u Values represent the mean of five replicates/treatment/site.

v Marketable yield/ha $=$ spear weight trimmed to $22.5 \mathrm{~cm}$.

${ }^{\mathrm{w}}$ Hamden, CT (sandy loam soil) and Windsor, CT (fine loamy sand soil); 5 replicates/site.

${ }^{\mathrm{x}}$ Formononetin $(20 \mu \mathrm{g} / \mathrm{ml})$ applied as a crown soak for $20 \mathrm{~min}$ at planting (May 1999) and as a crown drench (June 1999 and June 2000$)$ at 6.0 liters/row $(20 \mu \mathrm{g} / \mathrm{ml})$.

y $\mathrm{NaCl}$ applied June 1999 at $280 \mathrm{~kg} / \mathrm{ha}$ and June 200 at $560 \mathrm{~kg} / \mathrm{ha}$.

${ }^{\mathrm{z}}$ Mean was significantly different from the same plots in Hamden that did not receive formononetin at $P=0.063$ using Bonferonni's Test. 
isms as a factor in early decline of asparagus. Plant Pathol. 45:809-822.

7. Cohen, S. I., and Heald, F. D. 1941. A wilt and root rot of asparagus caused by Fusarium oxysporum (Schlecht). Plant Dis. Rep. 25:503509.

8. Dalton, B. R., Blum U., and Weed, S. B. 1983. Alleopathic substances in ecosystems: Effectiveness of sterile soil components in altering recovery of ferulic acid. J. Chem. Ecol. 9:1185-1201.

9. Debnam, J. R., and Smith, I. M. 1976. Changes in the isoflavones and pterocarpans of red clover on infection with Sclerotinia. Physiol. Plant Pathol. 9:9-23.

10. Elmer, W. H. 1992. Suppression of Fusarium crown and root rot of asparagus with sodium chloride. Phytopathology 82:97-104.

11. Elmer, W. H. 1995. The association among Mn-reducing bacteria and sodium chloride applications in the suppression of Fusarium crown and root rot of asparagus. Phytopathology 85:1461-1467.

12. Elmer, W. H., Johnson, D. A., and Mink, G. I. 1996. Epidemiology and management of diseases causal to asparagus decline. Plant Dis. 80:117-125.

13. Elmer, W. H., and LaMondia, J. A. 1999. Studies on the suppression of Fusarium crown and root rot with $\mathrm{NaCl}$. Acta Hortic. 479:211-218.

14. Graham, K. M. 1955. Seedling blight, a fusarial disease of asparagus. Can. J. Bot. 33:374-400.

15. Grogan, R. G., and Kimble, K. A. 1959. The association of Fusarium wilt and root rot with the asparagus decline and replant problem in California. Phytopathology 49:122-125.

16. Hartung, A., Nair, M., and Putnam, A. 1990. Isolation and characterization of phytotoxic compounds from Asparagus officinalis. J. Chem. Ecol. 16:1707-1733.

17. Hartung, A. C., and Stephens, C. T. 1983. Effects of alleopathic substances produced by asparagus on the incidence and severity of asparagus decline due to Fusarium crown rot. J. Chem. Ecol. 9:1163-1174.

18. Hartung, A. C., Stephens, C. T., and Elmer, W. H. 1990. Survey of Fusarium populations in Michigan's asparagus fields. Acta Hortic. 271:395-401.

19. Hazelbrook, J. P., Garrison, S. A., and Gianfagna, T. 1989. Alleopathic substances in asparagus roots: Extraction characterization and biological activity. Am. Soc. Hortic. Sci. 114:152-158.
20. Hoagland, D. R., and Arnon, D. I. 1938. The water culture method for growing plants without soil. Calif. Agric. Exp. Stn. Circ. 347.

21. Johnston, S. A., Springer, J. K., and Lewis, G. D. 1979. Fusarium moniliforme as a cause of stem and crown rot of asparagus, and its association with asparagus decline. Phytopathology 69:778-780.

22. Juniper, S., and Abbott, L. 1993. Vesiculararbuscular mycorrhizas and soil salinity. Mycorrhiza 4:45-57.

23. Komada, H. 1975. Development of selective medium for quantitative isolation of Fusarium oxysporum from natural soil. Rev. Plant Prot. Res. 8:114-124.

24. Kormanik, P. P., and McGraw A-C. 1982. Quantification of vesicular-arbuscular mycorrhizae in plant roots. Pages 37-45. In: Methods and Principles of Mycorrhizal Research. N. C. Schenck, ed. American Phytopathological Society, St. Paul, MN.

25. Lacy, M. L. 1979. Effect of chemicals on stand establishment and yields of asparagus. Plant Dis. Rep. 63:612-616.

26. Manning, W. J., and Vardaro, P. M. 1977. Soil fumigation and preplant fungicide crown soaks: Effects on plant growth and Fusarium incidence in newly planted asparagus. Plant Dis. Rep. 61:355-357.

27. Matsubara, Y., Ohba, N., and Fukui, H. 2001. Effect of arbuscular mycorrhizal fungus infection on the incidence of Fusarium root rot in asparagus seedling. J. Jpn. Soc. Hortic. Sci. 70:202-206.

28. Nair, M. G., Siqueira, J. O., and Safir, G. R. 1991. Isolation and identification of vesicular-arbuscular mycorrhiza stimulatory compounds from clover (Trifolium repens) roots. Appl. Environ. Microbiol. 57:434-439.

29. Ozan, A., Safir, G. R., and Nair, M. G. 1997. Recovery of exogenously applied isoflavones formononetin and biochanin A from soil and their effects on soil microbial populations. J. Chem. Ecol. 23:247-258.

30. Pedersen, C. T., Safir, G. R., Parent, S., and Caron, M. 1991. Growth of asparagus in commercial peat mix containing vesiculararbuscular mycorrhizal (VAM) fungi and the effect of applied phosphorus. Plant Soil 135:75-82

31. Pedersen, C. T., Safir, G. R., Siqueira, J. O., and Parent, S. 1991. Effect of phenolic compounds on asparagus mycorrhiza. Soil Biol. Biochem. 23:491-494.

32. Peirce, L. C., and Colby, L. W. 1987. Interac- tion of asparagus root filtrates with Fusarium oxysporum f. sp. asparagi. Am. Soc. Hortic. Sci. 112:35-40.

33. Phillips, J. M., and Haymans, D. S. 1970. Improved procedure for clearing root and stain ing parasitic and vesicular arbuscular mycorrhizal fungi for rapid assessment of infection. Trans. Br. Mycol. Soc. 55:158-163.

34. Poll, J. T. K., and Huiskamp, T. 1992. The effect of the asparagus re-plant problem in time. Asparagus Res. Newsl. 9:18-22.

35. Reid, T. C., Hausbeck, M. K., and Kizilkaya, K. 2001. Effects of sodium chloride on commercial asparagus and of alternative forms of chloride salt on Fusarium crown and root rot. Plant Dis. 85:1271-1275.

36. Schofield, P. E., Nichols, M. A., Long, P. G., and MacKay, B. R. 1997. A bioassay to monitor the autotoxin levels in asparagus replant soils. Acta Hortic. 479:237-245.

37. Shafer, W. E., and Garrison, S. A. 1986. Alleopathic effects of soil incorporated asparagus roots on lettuce, tomato, and asparagus. Hortic. Sci. 21:82-84

38. Siqueira, J. O., Safir, G. R., and Nair, M. G. 1991. Stimulation of vesicular-arbuscular mycorrhizal formation by flavonoid compounds, New Phytol. 118:87-93.

39. Tennant, D. 1975. A test of modified line-intersect method for estimating root length. J. Ecol. 63:995-1001.

40. Van Etten, H. D. 1976. Antifungal activity of pterocarpans and other selected isoflavonoids Phytochemistry 33:391-397.

41. Wacker, T. L., Safir, G. R., and Stephens, C. T. 1990. Effect of ferulic acid on Glomus fasciculatum and associated effect on phosphorus uptake and growth of asparagus (Asparagus officinalis L.). J. Chem. Ecol. 16:901909.

42. Wacker, T. L., Safir, G. R., and Stephens, C. T. 1990. Effect of Glomus fasciculatum on the growth of asparagus and the incidence of Fusarium root rot. J. Am. Soc. Hortic. Sci 115:550-554.

43. Walker, E. 1905. Asparagus and salt. Arkansas Agric. Exp. Stn. Bull. 86:31-36.

44. Yang, H. 1982. Autotoxicity of Asparagus officinalis. Am. Soc. Hortic. Sci. 107:860862.

45. Young, C. C. 1986. Autotoxication of Asparagus officinalis L. Pages 101-112 in: The Science of Alleopathy. A. R. Putnam and C.-S. Tang, eds. John Wiley and Sons, Inc., New York 